University of Michigan Law School

University of Michigan Law School Scholarship Repository

\title{
The Provincial Archive as a Place of Memory: The Role of Former Slaves in the Cuban War of Independence (1895-98)
}

Rebecca Scott

University of Michigan, rjscott@umich.edu

Available at: https://repository.law.umich.edu/book_chapters/12

Follow this and additional works at: https://repository.law.umich.edu/book_chapters

Part of the Comparative and Foreign Law Commons, Human Rights Law Commons, Law and Race Commons, Legal History Commons, Legal Writing and Research Commons, and the Military, War, and Peace Commons

\section{Publication Information \& Recommended Citation}

Scott, Rebecca J. "The Provincial Archive as a Place of Memory: The Role of Former Slaves in the Cuban War of Independence (1895-98)." In Archives, Documentation, and Institutions of Social Memory: Essays from the Sawyer Seminar, edited by F. X. Blouin Jr and W. G. Rosenberg, 280-90. Ann Arbor: University of Michigan Press, 2006. (Originally published under the same title in New W. Indian Guide 76, no. 3/4 (2002): 191-210.)

This Book Chapter is brought to you for free and open access by the Faculty Scholarship at University of Michigan Law School Scholarship Repository. It has been accepted for inclusion in Book Chapters by an authorized administrator of University of Michigan Law School Scholarship Repository. For more information, please contact mlaw.repository@umich.edu. 


\title{
The Provincial Archive as a Place of Memory
}

\author{
The Role of Former Slaves in the \\ Cuban War of Independence (I 895-98)
}

\author{
Rebecca J. Scott
}

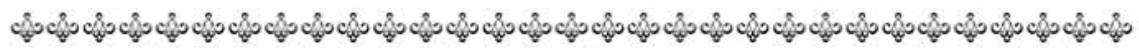

$\mathrm{F}^{\infty}$ ew questions of historical interpretation are more passionately debated than those that have become intertwined with a national narrative and with the definition of how a country came to be what it is imagined to be. For the island nation of Cuba, political independence was forged in a lengthy series of wars against Spanish colonial rule, ending in a direct encounter with U.S. expansionism. Those wars began in 1868 and concluded in 1898 with the departure of Spanish troops, followed by a military occupation of the island by U.S. forces. In 1902 the first Cuban republic emerged, but it was bound by the infamous Platt Amendment, which guaranteed to the United States a right of renewed intervention. The wars themselves were thus both a triumph and a defeat, a touchstone for national pride, and-in the outcomea source of nationalist disappointment.

Each political generation in Cuba interpreted the wars of independence anew, trying to incorporate the heroes and the dynamic of those wars into a story that legitimated-or, in the hands of critics, challenged-the subsequent order of things. After the victory of the Cuban revolution in $1958-59$, the new leadership undertook a process of socialist construction that was also a refusal of U.S. hegemony, and the active recollection of past struggles became a key element in the legitimation of current ones. By the I 970 s the sweep of Cuban history came to be officially described as cien años de lucha, "one hundred years of struggle." The r $895-98$ war and selected members of its pantheon of heroes-particularly José Martí and Antonio Maceo-had been folded into a con- tinuous battle against external imperial enemies and domestic antipatriots, and the 1959 triumph construed as the apotheosis of the formation of the Cuban nation. ${ }^{\mathrm{I}}$

Such an interpretation required that one of the most delicate questions in Cuban history-that of race and slavery-be handled in a somewhat gingerly way. Some of the heroes of the first war for independence ( $1868-78$ ) had been slaveholders. In the postrevolutionary context it became important to emphasize the moment at which they liberated their slaves rather than the long years during which they had profited from slave labor or the constraints they had imposed on those they nominally freed. ${ }^{2}$ Other officers and soldiers in the wars of independence had been former slaves or the descendants of slaves. In the climate of revolutionary enthusiasm after 1959, these earlier black and mulatto rebels came to be seen as the embodiment of a struggle for social justice as well as for national independence, their efforts to break the chains of colonialism a continuation of prior struggles to escape or break the chains of slavery. But it was important that they be seen to have struggled primarily as Cubans, striving toward a transracial national liberation and not as black rebels locked into an inconclusive conflict with a hesitant white nationalist leadership. In the postrevolutionary view, black and white rebels by I 895-98 shared ideals of racial "confraternity" that were later betrayed by the compromised twentieth-century republics but then vindicated by the more recent revolutionary process. ${ }^{3}$

In describing the national narrative in this way, I do not 
mean to suggest that it was merely a convenient invention or a conscious distortion. The story of the achievement of Cuban national independence is a stirring one, and the transracial ideal of Cuban nationality that held sway at the turn of the nineteenth into the twentieth century was an ideological and social achievement of remarkable dimensions to be impressed by Cuba's accomplishment, one has only to contrast it with the Anglo-Saxonism that had developed in the United States by midcentury or the systematic disfranchisement of African Americans allowed to stand by the U.S. Supreme Court in a key decision in 1903.4 The I9OI Cuban constitution, though often scorned for its incorporation of the Platt Amendment, was equally notable for its categorical guarantee of universal manhood suffrage, despite pressures from the U.S. occupiers to institute more restrictive measures. ${ }^{5}$ Cuban society, just fifteen years after slave emancipation, endorsed a formal definition of citizenship that mirrored the famous statement attributed to Antonio Maceo-that in Cuba there were neither whites nor blacks but only Cubans. This forthright assertion was grounded both in Maceo's principled antiracism and in the unity that he sought to build in the wars of independence. ${ }^{6}$ When the wars were over, one of the strongest guarantors of such equality was the presence of black veterans, whose sense of entitlement as citizens was unmistakable.

For historians, however, a coherent and in many ways admirable national narrative can be both an inspiration to research and a significant obstacle to understanding. By 1994-95, when the collective project I will describe shortly was taking shape, the currents of challenge to this aspect of the Cuban national narrative were unmistakable. In 1995 Aline Helg published an innovative work entitled Our Rightful Share: The Afro-Cuban Struggle for Equalily, 1886-1912, in which she criticized many of Cuba's national heroes and denounced what she saw as a "myth of racial equality" that "undermined the formation of a black collective consciousness." A key element of this myth, in her view, was a false portrait of the $1895-98$ war: "the myth inculcated the idea that racial equality had been achieved in the Cuban military forces that fought against Spain."7 At the same time, Ada Ferrer was completing a doctoral dissertation on race and nationality in the period of the Cuban wars of inde pendence, subsequently published as Insurgent Cuba: Race, Nation, and Revolution, I 868-1898. Ferrer demonstrated the continued coexistence within Cuban national ideology of both racism and antiracism. In contrast to Helg, Ferrer emphasized that nationalist ideas and the experience of shared military struggle served both as a weapon against discrimination and as a cover for discrimination. ${ }^{8}$

Within Cuba, young scholars had begun to pose questions about the remembering of national heroes and the representation of the mambi, the Cuban separatist soldier. ${ }^{9}$ The distinguished Cuban philosopher Fernando Martínez Heredia pointed more and more insistently to the role of racism in Cuban history-not racism as a "legacy" of slavery alone but racism as an active ideology integrally connected to Cuban nationalism. ${ }^{10}$ The historian Jorge Ibarra directly engaged Helg's portrait of the founding figures of Cuban independence, conceding portions of her argument while vigorously refusing her effort to locate the origins of the "myth of racial democracy" in the leadership of the Cuban revolutionary army of $1895-98$. Ibarra situated such mythmaking and opportunism as there was in the twentieth-century republic itself, not the independence struggle. ${ }^{11}$

In this context, the study of black and mulato soldiers in the wars of independence, their experiences and aspirations, and the opportunities and exclusions that they faced became a matter for urgent examination-and immediate contention. The presence of former slaves among the rebels, and of black officers within the insurgent ranks, was invoked on every side of the debate-yet even so basic a datum as their approximate numbers could not be estimated. Much of the polemic involved rereadings of familiar texts and attributions and reattributions of motives. Ferrer broke new ground by looking carefully at recruitment and surrenders, as reflected in Cuban and Spanish archives, and by giving a close reading to rebel correspondence and to the memoir literature, including the rarely cited autobiography of a black soldier, Ricardo Batrell Oviedo. But because Ferrer's focus was the entire island over the thirty years of anticolonial warfare, and because most lists of rebels included no racial labels, even she found it difficult to describe the social composition of the Ejército Libertador with precision.

A logical next step was to narrow the focus enough to get closer to the ground in a particular zone, to plunge into local and regional archives to see if there was some way to circumvent the silence on race imposed first by the record keepers and later by protective nationalists. In the mid-1990s, as politicians and scholars began to prepare for the centennial of the end of the $1895-98$ war, several historians were converging on a single region on the south coast of the island, Cienfuegos. During the second half of the nineteenth century, the river valleys of Cienfuegos had been ideal for the growing, processing, and transporting of sugar, and the region had developed 
into a major plantation zone. Cienfuegos was, moreover, a dramatic theater of war in the final independence struggle. With thousands of former slaves and a large rebel brigade, its history could provide an ideal case study.

More important, however, was the quality of its local archive. The Provincial Historical Archive, located on Twenty-seventh Street, just off the Plaza Martí, occupies the first floor of a converted house, next to a preschool playground and directly opposite a fire station. Researches and deliberations there are thus invariably accompanied, through the open windows, by sirens and diesel engines in times of fire or fire drill and, more often, by the young firemen's baseball practice, catcalls, and conscientious washing of the trucks with the fire hoses when there are no fires. The permeability of the reading room to sound is matched by the vulnerability of the whole building to weather: tropical storms blow holes in the roof, sending water pouring down. The decision of the upstairs neighbors to raise pigs on their terrace did not improve matters.

But the richness of the holdings and the vitality of the intellectual life in and around the archive compensate for these inconvenientes. Cienfuegos is a city known not only for its sugar-exporting port but also for its music, its architecture, and its revolutionary traditions. The archive's director at the time, Orlando García Martínez, born in a working-class neighborhood of the town and trained as a historian at the University of Las Villas during the I970s, had been tenacious in pulling documents of all kinds into the archive, while serving also as president of the provincial Union of Artists and Writers of Cuba (UNEAC). He has succeeded in preserving the municipality's voluminous notarial records, judicial records, and minutes of the town council, reflecting both the history of the town and the history of its agricultural hinterland. García, moreover, had developed a reputation for being willing to retrieve that which other state agencies plan to throw away, lining up trucks to bring the bundles to the archive instead of the paper recycling facility. Thus the Cienfuegos archive now holds some of the judicial records of the larger provincial capital of Santa Clara; the municipal records of the key sugar town of Santa Isabel de las Lajas; the original drafts of the 196 I cadastral survey of property in the entire region; and the before, during, and after writing samples of every person from Cienfuegos taught to read and write during the revolutionary Literacy Campaign of the early 1960 s. $^{12}$

García knows most of these collections of documents well and has long been writing the history of the region, including a close examination of its wartime experiences.
The archive's emergence as a locus for the study of race and revolution, however, dates to the arrival there in I 994 of a visiting researcher, Michael Zeuske. Born in Halle, East Germany, Zeuske was trained by the distinguished historian Manfred Kossok of the University of Leipzig, wrote his doctoral dissertation on an early nationalist movement in Venezuela, and prepared a second doctorate on Latin American independence struggles in comparative perspective. His scholarly formation inclined him to look at the big picture and to seek parallels between Latin American and European revolutions. But with the emergence of a movement of popular contestation on his home ground of Leipzig during 1989 , and the fall of the Berlin wall later that year, followed by the dramatic transformation of the East German academic climate, Zeuske chose to shift his research focus. He moved away from the macrostructural analysis of revolution and sought to understand a social movement from the inside. He decided, moreover, to undertake sustained research in Cuba, where he had lived as a boy in $1963-65$, when his father, Max Zeuske, had been a visiting East German specialist on assignment with the new revolutionary Cuban government, charged with assisting in the formation of the first worker-peasant university in Havana.

Michael Zeuske brought to the documentary riches of the Cienfuegos archives a new and inherently volatile question: what was the actual pattern of political incorporation of former slaves in rural Cuba after the abolition of slavery in 1886 ? Did they indeed join the anticolonial movement in large numbers in I895, or were they perhaps drawn into the webs of political clientelism that expanded as the Spanish colonial state lowered property requirements for voting and made room for a legitimated Cuban "autonomism" in the r 880 os and 1890 ? Zeuske began work in the archives of Santa Clara and Cienfuegos, compiling lists of rebel soldiers and scrutinizing them assiduously.

Painstaking scrutiny was necessary because racial labels almost never appear on lists of this kind. The strength of the transracial, or race-blind, ideal of nationality was such that Cuban separatists generally declined to record racial attributions when drawing up recruitment lists, and the victorious Cuban nationalists also refrained from including them when they compiled nominal records of rebel veterans. In effect, the written record was intentionally designed to ratify José Martí and Antonio Maceo's principle of race blindness. It thus erased evidence of racial distinctions. Even if such attributions had been consequential in social interactions and frequently uttered as explicit labels, they would not appear 
in the written record. The challenge for Zeuske was to find some way of identifying the social-and perhaps racial-categories that were behind the lists he had found but that the lists themselves never employed.

This same problem had plagued my own comparative work on postemancipation societies. In both Cuba and Brazil-in sharp contrast to the United States-former slaves were usually not identified as such in most written records, and thus from the point of view of the documents they vanished into a vast rural population, however unlikely it might be that their status as former slaves had disappeared in social practice. ${ }^{13}$ I was trying to work around this archival obstacle by identifying individual slaves who had lived on particular plantations and following them into freedom through plantation records for the 1880 os and 1890 s. Particularly detailed documents existed for two adjacent plantations-Soledad and Santa Rosalía-located a few miles from the town of Cienfuegos. I decided to restrict my focus to that region in hopes that I might learn enough through the history of identifiable individuals to be able to trace more generally the situation of former slaves and their descendants. So in I 996, I too ended up smelling the diesel of the fire trucks from the reading room of the Provincial Historical Archive of Cienfuegos.

The point here is not to marvel at the coincidences that brought three strangers together-one from central Cuba, one from Saxony, and one from Michigan-and turned them into friends and collaborators. After all, life is full of such coincidences. What is more interesting is the way in which working in a specific regional archive nourished three different methodological approaches to these questions and opened up possibilities for expansion of the research itself, particularly through the avenue of oral history. The oral histories in turn "electrified," to use Michael Zeuske's phrase, the whole enterprise. I shall briefly sketch the three methodologies and the preliminary findings and then turn to the oral history - at which point the archive appears, as in my title, as a place of active remembering rather than simply a place of documents.

First, Zeuske's approach. Concentrating on the lists of recruits that he had compiled and on the Cienfuegos sugar zones of Santa Isabel de las Lajas and Cruces, he set out to estimate the proportion of those in the rebel ranks who were actually former slaves, based on what he described as a "structural/name-based" technique. After identifying what he believed to be the major "slave surnames" for Lajas and Cruces, those adopted by slaves from the largest plantations as they achieved their freedom, he combed the enlistment records to find them. To our collective surprise he came up with very low estimates of the numbers of former slaves among the rebels. He even noted that the names of former slaves from Lajas and Cruces were more likely to be found on the lists of those who voted in the colonial elections in favor of the mild-mannered Autonomists than in the ranks of the Cuban rebels. When he began to present these results, several of us critiqued his methods and thought that his estimates had to be wrong. ${ }^{\mathrm{I}}$ In all of our minds, the independence war has long been linked to the fight against slavery, and it seemed somehow logical that former slaves would naturally gravitate to the rebel ranks. What did it mean if they did not?

Based in the archive itself, with very few material resources but a great deal of determination, Orlando García decided in 1997 to tackle the issue of the social composition of the Liberation Army head-on, undertaking the compilation of a relational database that would include every soldier who served in the Cienfuegos Brigade of the rebel army between 1895 and 1898 . Using pension records, manuscript recruitment lists, notarial archives, and published lists of veterans, he began to develop not a mere sample but a complete portrait of one brigade. By the brute-force method of reading every available record, he would try to create a minibiography for each soldier. In the process, he came across racial labels for individuals in collateral records, particularly the baptismal records sometimes included with pension requests, even though such labels are absent from the military records. He was by this means able to develop something of a statistical profile of the composition of the force-though, of course, the racial labels, like any contingent and relational social construction, shift and turn from document to document.

The risks and the benefits of this strategy are equally clear. It takes the patience of a saint to assemble and complete over a thousand such personal dossiers, rigorously maintaining the source references necessary to follow up on any detail as necessary. Moreover, computers are notoriously unhappy in a humid tropical environment beset by power outages. But García succeeded. At an international conference held at the Cienfuegos archive in March 1998 he shared the first results, jolting one of Cuba's most distinguished historians, Jorge Ibarra, into a vigorous counterattack.

García argued that there were, in effect, two successive rebel armies in Cienfuegos. The first dated to $1895-96$ and was predominately composed of men from the countryside, many of them black and mulato. The early recruitment of rebels seems to have mirrored the composition of 
the rural working population of the Cienfuegos hinterland and thus was nearly equally divided between those who traced their ancestry primarily to Spain or the Canary Islands and those who traced it to Africa. Casualties in the early encounters with the Spanish forces were high. After a dramatic and disastrous set of rebel reverses in 1897 , which brought large numbers of surrenders, the war settled into a harrowing stalemate. Net recruitment to the insurgent ranks fell below zero. Following the explosion of the U.S. battleship Maine in early 1898 , however, it began to appear likely that the United States itself would enter the war and that Spain might actually lose. In 1898 new Cuban recruits to the rebellion appeared-but this time they were disproportionately white and urban, of some schooling, often professionals. By rebel policy, even if they did not have military training or experience, their degrees gave them immediate access to officer status, thereby privileging them over longer-serving and more experienced black and mulato soldiers. ${ }^{15}$

When the war ended in late 1898 , many of the officers of this "second army" stepped forward to inherit the nationalist mantle-but many of the earlier black and $m u$ lato officers and soldiers had been killed in battle or by disease or were consciously sidelined. ${ }^{16}$ The chronology sketched by García for the Cienfuegos Brigade makes it easier to understand how very disparate images of race and the war experience might coexist, encompassing both a memory of black leadership and cross-racial collaboration, from 1895 through 1897 , and a sense of displacement of black officers and soldiers by white ones, particularly as the war came to a close in 1898 .

García's findings also helped to explain why the war might raise very high expectations among Cubans of African descent, expectations that when disappointed would leave a legacy of bitterness. It is at this juncture that his findings intersected with the question of the defining of freedom in a postemancipation society. I had for some years been reading the correspondence of the administrators of the Santa Rosalía sugar plantation, papers that had come to rest-after the expropriation in the early 1960 of major sugar properties-in the National Library in Havana. I had also been gathering information on the adjacent Soledad plantation, owned after I $88_{4}$ by Edwin Atkins of Belmont, Massachusetts. These estates together held several hundred slaves and were situated at the edge of and in the midst of the fighting during the $1868-78,1879-80$, and $1895-98$ wars. Unlike Zeuske and García, I had begun not with lists of insurgents but with lists of slaves and workers, and then I worked forward, trying to figure out who had joined the insurgency and why and what had become of those who did not join. The administrators' correspondence made it clear that men with the surnames Sarría and Quesada, former slaves on these two estates, were important figures in the rebellion. The administrators insulted and disparaged them as bandits but could not ignore them. Moreover, since I was tracing individuals, I was able to follow the paths of men and women who were involved with the insurgency in various ways, including those men who later left the rebel ranks. ${ }^{17}$

As I reconstruct the process of collective discoveryand I may be making it more linear and logical than it seemed at the time-we were able to break through the apparent contradictions of our various findings thanks to a series of fortuitous documentary discoveries and to the emergence of the Cienfuegos Provincial Historical Archive in the spring of 1998 as a place of shared memory as well as scholarly inquiry. The very openness of the space of the archive to the world of Cienfuegos beyond it, such a risk for the documents that reside there, became a new source of life for the history they recorded.

Early in my research I had stumbled on a receipt for a mule claimed by a former slave, Ciriaco Quesada, after a showdown with the administrator of the Santa Rosalía plantation in August 1899 . The more closely I examined this incident, the more I became convinced that it reflected a widespread contest over rights to property and citizenship in the immediate aftermath of the war, one in which black and mulato veterans played an important role. ${ }^{18} \mathrm{I}$ began to wonder whether anyone named Quesada, descended from those families from Santa Rosalía, might still live in Cienfuegos. An ideal place to pose that question, it turned out, was the Provincial Archive itself. Schoolteachers and retired lawyers and schoolchildren and poets and anyone needing a copy of a notarized document eventually end up at one of the tables in the reading room. When I mentioned my interest in locating individuals named Quesada to Félix Tellería, who is a babalao (santería priest), a geographer, and a colleague of Orlando García in the Cienfuegos branch of UNEAC, he recalled that one of his neighbors was a former schoolteacher named Araceli Quesada y Quesada. He thought her family might indeed have come from Soledad or Santa Rosalía. He would talk with her.

When I arrived at the archive a few days later, Araceli Quesada y Quesada was waiting for me, a flower in her hair and a sheaf of papers in her hands. She explained that she was only in her sixties and therefore did not have memories going back terribly far-but that her aunt, Caridad Quesada, now blind and in her late sev- 
enties, knew a great deal. When Araceli Quesada heard from Félix Tellería that I was doing research on Santa Rosalía, she took the initiative of asking her aunt some questions and compiled about ten pages of notes on their conversation. Would I be interested in talking them over?

Caridad Quesada's memory, it turned out, was filled with stories, detailed genealogies, and songs, including epic political ballads sung by her uncle Cayetano Quesada. She also had been carefully taught the names of her cousins, near and far, so that she wouldn't marry one by accident-and she was able to trace out the relations among dozens of the descendants of former slaves of Santa Rosalía. By the time we finished going over these notes with Araceli Quesada, Orlando García and I quickly decided that at the conference we were organizing for March 1998 we would invite members of the Quesada and Tellería families to participate in a roundtable on memories of the postslavery period.

That roundtable, during which Caridad Quesada burst into song, was a turning point. The quest for evidence now seemed to belong to the Quesadas and Tellerías as well as the historians. Moreover, one member of the audience invited us to meet his grandfather, Tomás Pérez y Pérez, age ninety-six, who had worked all his life on Soledad. Tomás Pérez, it turned out, had known Ciriaco Quesada, the protagonist in the 1899 battle over the mule. "He was a tall man, quite thin." The microhistory of Santa Rosalía began to take on weight and volume.

The methodology that emerged was a pragmatic and improvised one. Because our research was based in a local archive whose director knew half the town-and the other half knew him-personal recollections and documentary evidence tumbled over each other every day. Caridad Quesada spoke to us about her uncle Cayetano Quesada, born to a slave mother on Santa Rosalía. His veteran's pension record was there in the archive, and we could double-check birth dates and the service record, verify residence, and have the material for new questions. We followed these clues out into the countryside, walking the trail that Ciriaco Quesada had ridden the day of the showdown over the mule-and finding the house where Cayetano Quesada's daughter, Ramona Quesada de Castillo, still lived. She, in turn, talked about her father. We learned that Cayetano and Ciriaco Quesada had lived side by side on a plot of land in the hamlet of San Antón. Her brother Humberto Quesada, who still cultivates that sitio, showed us the avocado tree that their grandfather Alejandro had apparently planted after the family achieved full legal freedom from slavery and moved to settle a few miles away from the Santa Rosalía plantation.

Oral history, of course, has some awkwardness that archival research does not. One morning when I reached the archive, Félix Tellería's father, Fermín, was waiting. He had some family papers in his shirt pocket, and he had come to speak with me about his father, Trino Tellería, also a veteran of the $1895-98$ war. We had already located Trino Tellería's pension record in the archive, so I read it aloud to Fermín — and faced the embarrassing moment when I realized that the pension request had been filed in 1937 by Fermín's sister, Nazaria, who in the course of her petition had sworn that she had no brothers or sisters. Fermín Tellería looked more or less bemused by this implied denial of his existence and I learned a quick lesson about the misleading formalisms that sometimes undergird seemingly rigorous written documentation. ${ }^{19}$

In sum, the rough-and-ready technique of sharing written records orally and of recording oral testimony in writing made possible a dialogue between types of sources that seemed to accelerate the research process exponentially. But what of our early questions about Afro-Cuban participation in the $1895-98$ war? On the one hand, it seemed to be everywhere-we had found an abundance of grandparents, parents, and uncles who had been veterans. On the other hand, its linkage to slavery now appeared to have a twist. Often the black veterans who had survived in memory were not precisely former slaves. As we traced the genealogies and linked names to slave lists, we found that a common pattern was for the soldier to be the freeborn son of a slave mother or of parents held under the patronato, the notional "apprenticeship" that was imposed on most slaves at the time of formal abolition in 1880 . In other words, the process of gradual emancipation in Cuba had-by freeing children beginning with those born in 1868 but retaining working-age adults in bondage into the 1880 - created a very particular category of young man: one whose own legal status was that of nominal freedom but who had grown up largely within the world of slavery to which his mother, and often his father, still belonged.

Here was part of the answer to the puzzle posed by Michael Zeuske's early findings. It may well be that former slaves from the largest sugar plantations in Cienfuegos-those whom he identified through their possession of classic "slave surnames" like Zulueta, Terry, and Moré- were in fact relatively rare among the recruits to the rebel army. The most productive plantations, owned by the wealthiest entrepreneurs, were fortified to prevent 
both rebel incursions and rebel recruitment. Moreover, the great majority of their former slaves were by 1895 well over the age of thirty, with many over forty or over fifty. But at the edges and in the interstices of the sugar zones, and in the mid-sized plantations like Santa Rosalía, much less well fortified, there were former slaves in their thirties, like Ciriaco Quesada, who joined forces with coworkers to form the rebel bands that emerged early in the war. There were also muchachones, young men in their teens or early twenties, born free, who were responsive to appeals to join the rebellion in the summer and fall of $1895 .{ }^{20}$

Caridad Quesada's uncle Cayetano Quesada was just such a muchachón, born free to a slave mother, and he joined up at the age of seventeen. With Cayetano Quesada's trajectory in mind, Michael Zeuske went back to a sample of thirty-seven well-documented requests for back pay filed by the surviving families of black and $m u$ lato rebel soldiers killed during the war. Sure enough, the free sons of slave mothers emerged as an important group among these soldiers, recruited alongside a smaller number of men who were themselves born into slavery and another group born to long-free families of color. ${ }^{21}$

In conjunction with Zeuske's and García's statistical data, the life histories built up through this encounter of documents and memories suggest a new way of thinking about the question of black and mulato participation in the war. Rather than envisioning a diffuse and continuous set of "struggles" for freedom-in which the fight for personal freedom leads naturally to participation in the fight for national freedom-we can try to locate the recruits themselves in the precise social fields in which they operated. We can situate them within families and gain some sense of the accounts they might have wished to settle with the state that had sanctioned slavery and in some cases with the individuals who had held their parents in bondage. We can explore whether their relative youth and physical mobility brought them in contact with revolutionary activists and whether plantation work groups served as nuclei for rebel bands.

Tracing the process of recruitment this way provides no magic key to motivation-a target that always seems elusive, no matter how carefully one refines one's methodology. But assembling such life histories and situating them within the history of these plantations can provide a sense of the social composition and work experience of the small groups who came together before and during the war. These "bands," often operating under highly personalized leadership, took to the woods around the Soledad plantation in 1895 , stealing horses, torching cane, and settling grudges-and furthering the cause of Cuban independence, indirectly or directly. Later they would be constituted as formal companies of the Cienfuegos Brigade.

These groups seem to have emerged from the war as clusters of individuals bound by mutual loyalties and shared antagonisms-and undoubtedly divided by some rivalries. Armed, mounted, and quite sure of their own strength, they were quick to contest attempts to place limits on their freedom and citizenship. They could join forces, for example, to help one of their number keep a horse acquired during the war by testifying on his behalf at the property registry to the legitimacy of his claim, enabling him to acquire title under procedures set up by the U.S. occupation government. And in the case of Ciriaco Quesada, they could back up his claim to recover a mule once the war was over-a mule that the administrator at Santa Rosalía certainly did not want to turn over to the Quesada family. ${ }^{22}$

By looking closely at these small groups and their members one can see the storied "cross-racial" alliances as very concrete things, while at the same time glimpsing some of the fracture lines within them, lines that could widen with time. The same comrades who might stand together at the property register in Arimao could be wedged apart by the scheme of racial privilege that governed employment on the Soledad plantation. ${ }^{23}$ They could then be united again in the electoral alliances, particularly of the Liberal Party, that were made possible by the I90I constitution and its guarantee of universal manhood suffrage.

Tracing individuals one by one, we also learn some of the subtle markers of color and status, coded references that at first appeared mere formalities. Revolutionary record keepers had emphasized the equality of Cuban citizenship by refusing to add the old colonial color labels-pardo, mulato, moreno, negro-to the names of recruits as they drew up enlistment registers. Moreover, they often avoided further invidious distinctions by eschewing the use of doubled surnames, the classic Iberian signal of legitimate descent. ${ }^{24}$ But this formal egalitarianism could be undercut elsewhere by the conventions of notaries who drew attention to-or even imposed-distinctions in naming patterns that encoded status and perhaps color. Thus in Nazaria Tellería's pension request she was listed as Nazaria Tellería SOA-sin otro apellido, "without another surname." Ordinarily using a single surname signaled illegitimacy, as the child born outside marriage could claim the mother's surname but not a paternal surname. ${ }^{25}$ For Nazaria Tellería, however, this was 
clearly not the case- she had been recognized by her father and she used his name. The gratuitous placing of the three-letter initial SOA after her name may well have been linked to a detail that was mentioned explicitly elsewhere in the document: that she and her father were categorized as mestizo, the common Cuban term implying mixed African and European ancestry, often used as a genteel label for those who had earlier been denominated pardo or mulato. The republican notaries had quietly adapted a label from the late colonial era, using it to call attention to the status of those who now appeared before them as Cuban citizens. ${ }^{26}$

\section{Conclusion}

Studying the racial fault lines of a society that has tended to deny them is often a thankless task. Moreover, and ironically, one runs the risk of overinsisting on the salience of color, precisely because the history of denial is so strong. By focusing on a single locality, the three of us have pieced together one strategy for working on and around this problem. For the relatively small number of individuals whose genealogy or social circumstances we can trace in detail, we are able to examine directly the situation of descendants of slaves in central Cuba, without relying on intervening markers of slave ancestry that may or may not appear in a given body of documentation. Independent of whether Cayetano Quesada is referred to by a color label in a particular written record, we know that his parents were slaves on the Ingenio Santa Rosalía. His recruitment to the Liberation Army during its first months thus stands as a direct instance of a young man born free into the world of slavery who chose the path of insurgency. His life history, in conjunction with those of his neighbors Ciriaco Quesada, Claudio Sarría, Rafael Iznaga, and others, may help illuminate the process by which such men made similar choices. ${ }^{27}$ At the same time, the life history of his neighbor Ramos Quesada, who remained on the Santa Rosalía plantation during the war to guard the cattle against rebel incursions, may illustrate another sort of choice. ${ }^{28}$

Continuing the story beyond 1898 , through the U.S. occupation and into the first years of the republic, it be comes possible to make progress in examining the multiple legacies of the rebellion. We seldom know for certain the thoughts and motivations of soldiers, yet traces have been left in the way in which Cuban veterans established claims to property and citizenship after the war. Their assertions of entitlement as patriots, alongside their often complex negotiations within the entangling webs of an emerging system of clientelism, begin to speak for them. ${ }^{29}$

In this particular provincial archives, as in other local archives in Cuba, the key records are located not in careful seclusion but in a building whose door opens, both literally and figuratively, onto the street. The Quesada, Pérez, and Tellería kin did not hesitate to bring additional documents and photographs to the project, taking various initiatives, commenting on our preliminary findings, and suggesting interpretations, almost from the beginning. Questions of race in Cuba and elsewhere are delicate, but we have found that they need not be unspeakable. The "social construction of race" is an ongoing process that people can and do talk about, not just a now fashionable analytic label. Tomás Pérez y Pérez, son of an ex-slave mother and a Spanish immigrant father, knew very well that the racial labels attributed to him varied according to context, and he was willing to reflect aloud on the ways this affected his employment and the social situation of his family. Ramona Quesada had also thought about the "blackness" of her father and herself as descendants of the slaves on Santa Rosalía-as well as the "whiteness" of her husband, Evelio, as a descendant of Canary Islanders. The "social construction of race" is an often brutal process, and these life histories help to illuminate its unfolding in a notionally race-blind republic. ${ }^{3 \circ}$

Here lies the unanticipated benefit: precisely because we have been able to trace slave ancestry with relative precision, we need not assume and impute a fixed meaning to that ancestry. And because we need to explain our findings along the way to those who knew many of the people we are writing about, we are particularly open to challenge and clarification. By anchoring our hypotheses in an ever widening and ramifying set of life histories, we can, if appropriate, let go of the revisionist zeal to insist on the primacy of racial discrimination at the same time as we relinquish the heroic picture of revolutionary unity. The resulting stories become more complex, taking shape both within the historiography as it is now emerging and within the community of Cienfuegos itself.

But what of the national narrative? Did we, like good fin de siècle students of the subaltern, overturn the national narrative?

I suppose not quite. Instead, we expanded our sense of the elements that have to be accounted for in any such narrative. The construction and interpretation of these life histories and collective biographies might be seen as an attempt to fulfill the goal set out by Arlette Farge in her work on the historian in the archive. In her text, Farge implicitly recalls the romantic conviction expressed 
by Jules Michelet that the historian can exhume and restore life to the dead through work in the dust of the archive. ${ }^{31}$ Gently rebuking such a presumption, Farge suggests a more open-ended, and ultimately collaborative, picture.

On ne ressuscite pas les vies échouées en archive. Ce n'est pas une raison pour les faire mourir une deuxième fois. L'espace est étroit pour élaborer un récit qui ne les annule ni ne les dissolve, qui les garde disponibles à ce qu'un jour, ct aillcurs, une autre narration soit faite de leur énigmatique présence.

(One does not bring back to life those whom we find cast up in the archive. But that is no reason to make them suffer a second death. And the space is narrow within which to develop a story that will neither cancel out nor dissolve these lives, that will leave them available so that one day, and elsewhere, another narrative may be built from their enigmatic presence.) $)^{32}$

\section{NOTES}

With the collaboration of Orlando García Martínez (Unión Nacional de Artistas y Escritores de Cuba-Cienfuegos) and Michael Zeuske (Universität zu Köln), this essay was presented at the Boston-area workshop on Latin American history held at the David Rockefeller Center for Latin American Studies. Scott, García, and Zeuske would like to thank the participants in both the Michigan and the Harvard seminars, particularly Francis Blouin, Monica Burguera, Alf Luedtke, William Rosenberg, John Coatsworth, and Barbara Corbett. Scott also thanks George Reid Andrews, Sueann Caulfield, Alejandro de la Fuente, Ada Ferrer, Aims McGuinness, Peter Railton, Anne Scott, John Scott-Railton, and Thomas Scott-Railton for helpful suggestions on the text. The essay has been published in the New West Indian Guide/Nieuwe West-Indische Gids 76 (2002) and in History Workshop Journal 58 (2004).

I. For an early and careful examination of the ideology of one hundred years of struggle, see Louis A. Pérez Jr., "In the Service of the Revolution: Two Decades of Cuban Historiography, 1959-79" (1980), reprinted in Louis A. Pérez Jr., Essays on Cuban History: Historiography and Research (Gainesville: University Press of Florida, 1995).

2. Already in I96I the Afro-Cuban Marxist philosopher and activist Walterio Carbonell saw this as a misguided strategy and called on the revolutionary leadership to cease seeking validation through the canonization of slaveholding founding fathers. Carbonell later ended up ostracized, his position apparently characterized as racially divisive. See the impassioned plea, dedicated to "Fidel and the new generation of writers," in Walterio Carbonell, Crítica: Cómo surgió la cultura nacional (Havana: Ediciones Yaka, 196r). On Carbonell's subsequent fate, see Hugh Thomas, Cuba: The Pursuit of Freedom (New York: Harper and Row, 1971), 1433.

3. A subtle and enduring expression of this national narra- tive is Miguel Barnet, Biografía de un Cimarrón (Havana: Instituto de Etnología y Folklore, 1966). The classic enunciation by a historian is in the eloquent Ideologia mambisa by Jorge Ibarra (Havana: Instituto Cubano del Libro, I972): “Al proclamar la confraternidad étnica, la igualdad jurídica y la libertad política, la vanguardia revolucionaria del 68 [1868] sentaba las bases definitivas para la formación de la nación cubana" (2I). For an interesting critical view from the prerevolutionary period, see Raúl Cepero Bonilla, Azúcar y abolición (Havana: Editorial Cénit, 1948).

4. On the national, as opposed to simply Southern, dimensions of the endorsement of black disfranchisement in the United States, see Richard H. Pildes, "Democracy, AntiDemocracy and the Canon," Constitutional Commentary 17 (2000): 295-319.

5. The pioneering work on the debate concerning suffrage is that of Alejandro de la Fuente, first published in "Myths of Racial Democracy: Cuba, I900-1912," Latin American Research Review 34 (1999): 39-73, and elaborated in A Nation for All: Race, Inequality, and Politics in Nineteenth-Century Cuba (Chapel Hill: University of North Carolina Press, 200I).

6. Ibarra, Ideologia, 51, gives the phrase as "Joven, aquí no hay blanquitos, ni negritos, sino cubanos." Ibarra dates it to I 870 but unfortunately gives no primary source citation. The meaning of the phrase itself, if these are indeed the words Maceo uttered, is ambiguous, for he uses not the terms blanco and negro, which could be construed as racial descriptors, but blanquitos y negritos, diminutive terms that could be seen as derogatory. It is thus not entirely clear whether Maceo was rejecting racial categories as such or their derogatory variants.

7. Aline Helg, Our Rightful Share: The Afro-Cuban Struggle for Equality, I886-19I2 (Chapel Hill: University of North Carolina Press, 1995), 16.

8. Ada Ferrer, Insurgent Cuba: Race, Nation, and Revolution, $1868-1898$ (Chapel Hill: University of North Carolina Press, 1999). See also de la Fuente, A Nation for All, for a distinction between racial democracy as a project and racial democracy as a fait accompli.

9. One such study subsequently appeared as a book: Blancamar León Rosabal, La voz del Mambí: Imagen y mito (Havana: Editorial de Ciencias Sociales, I997).

Io. See Fernando Martínez Heredia, "El Problemático Nacionalismo de la Primera República," Temas (Havana), 24-25 (January-June 200I): 35-44. An expanded version, translated by Lara Putnam, appears in English in Cuban Studies 33 (2002): 95-I23, with the title "Nationalism, Races, and Classes in the Revolution of 1895 and the Cuban First Republic."

II. See the essay by Jorge Ibarra, "Comentarios acerca de 'Mitos de democracia racial: Cuba, I900-1912,'” in Fernando Martínez Heredia, Rebecca J. Scott, and Orlando García Martínez, eds., Espacios, silencios, y los sentidos de la libertad. Cuba, I 878-1912 (Havanà: Editorial Unión, 2001; réprint, Havana: Editorial de Ciencias Sociales, 2002), 332-45. As with the work of Martínez Heredia, Ibarra's criticisms circulated orally and in typescript for some time before reaching print.

I2. For a guide to the holdings of this and other provincial, municipal, and local archives, see Louis A. Pérez Jr. and Rebecca J. Scott, eds., The Archives of Cuba/Los archivos de Cuba (Pittsburgh: University of Pittsburgh Press, 2002). 
13. See the afterward to Rebecca J. Scott, Slave Emancipation in Cuba: The Transition to Free Labor, I860-1899, $2 \mathrm{~d}$ ed. (Pittsburgh: University of Pittsburgh Press, 2000), and the introduction to Scott et al., The Abolition of Slavery and the Aftermath of Emancipation in Brazil (Durham, NC: Duke University Press, 1988).

I4. See Michael Zeuske, "'Los negros hicimos la independencia': Aspectos de la Movilización Afrocubana en un Hinterland Cubano. Cienfuegos entre Colonia y República," paper presented at a conference in the Cienfuegos Provincial Historical Archive, March 1998, and published in Martínez, Scott, and García, eds., Espacios, silencios, I93-234.

I 5. See Orlando García Martínez, "La Brigada de Cienfuegos: Un Análisis Social de su Formación,” in Martínez, Scott, and García, eds., Espacios, silencios, 163-92. It was on this last point that Ibarra disagreed, arguing that the privileging of training and education was simply necessary to provide professionals such as doctors for the army. García countered with the statistics showing that the number of doctors and lawyers was very small and argued that officer status functioned as a class and racial privilege rather than a pragmatic measure.

I6. The best study of the dynamics of the process of sidelining is the essay by Ada Ferrer on the court martial of Quintín Bandera, "Rustic Men, Civilized Nation: Race, Culture, and Contention on the Eve of Cuban Independence," Hispanic American Historical Review 78 (November 1998): 663-86.

17. This research has now been incorporated into Rebecca J. Scott, Degrees of Freedom: Louisiana and Cuba after Slavery (Cambridge, MA: Harvard University Press, forthcoming).

I8. An early version of this inquiry was presented at the I 998 conference in Cienfuegos and was published as Rebecca J. Scott, "Reclamando la Mula de Gregoria Quesada: El Significado de la Libertad en los Valles del Arimao y del Caunao, Cienfuegos, Cuba (I880-I 899)," Illes i Imperis (Barcelona) 2 (spring 1999): 89-107, and then in Martínez, Scott, García, eds., Espacios, silencios, 23-52. A revised version appeared as "Reclaiming Gregoria's Mule: The Meanings of Freedom in the Arimao and Caunao Valleys, Cienfuegos, Cuba, r880-1899," Past and Present (February 200I): I8I-2I6.

I9. Pensión interesada por Nazaria Tellería, como hija del veterano Sr. Trino Tellería Santana, Año de 1937, in Fondo Juzagado de Primera Instancia de Cienfuegos, AHPC. Trino Tellería had in 1929 formally recognized his paternity of Nazaria Tellería, born in 1901. She first asserted in her 1937 pension request that her father had never been married and hence had left no other legitimate or recognized children. Later in the document she swore that he had left no other natural or legitimate children. This was misleading, since the children of even an unrecognized union were hijos naturales if the parents had been in a condition to marry at the time of the birth-that is, if the union was not adulterous, bigamous, or otherwise prohibited. (Fermín Tellería's birth-to thè same father and mother-had probably been recorded in the town of $\mathrm{Ca}$ marones rather than in Cienfuegos).

20. The general dynamic of recruitment in the region is discussed in Scott, "Reclaiming Gregoria's Mule"; and García Martínez, "La Brigada de Cienfuegos."

21. See Michael Zeuske, "Lux Veritatis, Vita Memoriae, Magistra Vitae-I 6 Vidas y la Historia de Cuba," in Historia y memoria: Sociedad, cultura y vida cotidiana en Cuba, I878I 917 (Havana: Centro de Investigación y Desarrollo de la Cultura Cubana Juan Marinello, 2003), 55-8I.

22. On the right to register horses and the claim for the mule, see Scott, "Reclaiming Gregoria's Mule."

23. The question of racial privilege on the Soledad estate has become clearer as the correspondence of the owner and administrator has come to light. See the correspondence of Edwin F. Atkins in the Atkins Family Papers, Massachusetts Historical Society, and an initial discussion in Rebecca J. Scott, "Race, Labor, and Citizenship in Cuba: A View from the Sugar District of Cienfuegos, I 886-1909," Hispanic American Historical Review 78 (November 1998): 70 .

24. See, for example, the enlistment register for the third company of the first battalion of the Regimiento de Infantería "Cienfuegos," in Expediente 60, Inventario 1, Documentos relativos a la inspección general del Ejército. . 27 de Noviembre de 1896 , Colección de documentos del Ejército Libertador, Archivo Histórico Provincial de Villa Clara, Santa Clara, Cuba (photocopies in the possession of Michael Zeuske). In this list the ex-slave soldier Ciriaco Quesada is listed with a single surname, as are all the other soldiers and officers in the company.

25. On the rules governing the use of surnames, see Rafael Pérez Lobo, compiler, Código Civil y Constitución (Havana: Cultural, 1944), articles II9-4I of the I 889 Civil Code. The stigma associated with the single surname is suggested by the I 927 ruling that gave even "natural children" the right to use a double surname: "En la inscripción de hijos naturales se hará constar a los efectos del caso primero de este art., el apellido completo paterno y materno de la persona que lo reconozca, a fin de que, siendo en esta forma usado por dichos hijos, no revelen obstensiblemente la ilegitimidad de su origen" (Resol. Secr. Justicia I 5 July 1927,47 ).

26. The question of "race marking" in late colonial and republican Cuba is a complex one, and these observations on the use of the initials SOA are quite preliminary. See Michael Zeuske, "Hidden Markers, Open Secrets: On Naming, RaceMarking and Race-Making in Cuba," New West Indian Guide/Nieuwe West-Indische Gids 76 (2002): 2 I I-42.

27. See Rebecca J. Scott, "Tres Vidas, una Guerra. Rafael Iznaga, Bárbara Pérez y Gregoria Quesada entre la Emancipación y la Ciudadanía," in Historia y memoria.

28. On Ramos Quesada, see the correspondence to and from Santa Rosalia that is held in the Fondo Manuscrito Julio Lobo, Biblioteca Nacional "José Martí," Havana; and David Sartorius, "Conucos y Subsistencia: El Caso del Ingenio Santa Rosalía," in Martínez Hereolia , Scott, and García Martínez, eds., Espacios, silencios, 108-27. The doctoral dissertation by Sartorius ("Limits of Loyalty: Race and the Public Sphere in Cienfuegos, Cuba, I845-1898," Ph.D. diss., University of North Carolina, 2003) examines the phenomenon of loyalty to the Spanish state on the part of some Cubans of color.

29. On this point, see Rebecca Scott and Michael Zeuske, "Property in Writing, Property on the Ground: Pigs, Horses, Land, and Citizenship in the Aftermath of Slavery, Cuba, 1880-1909," Comparative Studies in Society and History, 44 (2002): 669-99.

30. For a vivid picture of an equally complex process on the 
shifting terrain of the border states and upper south in the United States, see Pauli Murray, Proud Shoes: The Story of an American Family (New York: Harper and Brothers, 1956).

3I. Jules Michelet wrote: "J'ai donné à beaucoup de morts trop oubliés l'assistance dont moi-même j'aurai besoin. Je les ai exhumés pour une seconde vie," Jules Michelet, Histoire du xix $x^{e}$ siècle, vol. 2, Jusqu'au 18 Brumaire ( 1872$)$, preface, in Michelet, Oeuvres Complètes (Paris, 1982), 21, 268. The ref- erence to his own future need for exhumation becomes clearer in the light of an earlier draft, cited in the editors' note 4: "Je mourrai bientôt et moi-même, avec mes longs travaux, je serai un souvenir, un fait du $19^{c}$ siècle dont j'écris l'histoire." See also Carolyn Steedman, "The Space of Memory: In an Archive," History of the Human Sciences II (1998): 65-83.

32. Arlette Farge, Le goût de larchive (Paris: Editions du Seuil, 1989), 145; translation mine. 